\title{
PENGARUH PENGENDALIAN INTERNAL DAN ASIMETRI INFORMASI TERHADAP KECENDERUNGAN KECURANGAN AKUNTANSI
}

\section{(Penelitian Persepsi Pengelola Keuangan pada Perguruan Tinggi Negeri BLU)}

\author{
Biaini Naeli Muna 1, Lutfi Harris 2* \\ * Fakultas Ekonomi dan Bisnis Universitas Brawijaya \\ * M.T Haryono 165 Malang, 65145, Indonesia \\ E-mail: lutfi.h@ub.ac.id
}

\begin{abstract}
Abstrak
Penelitian ini bertujuan untuk mengetahui pengaruh pengendalian internal dan asimetri informasi terhadap kecenderungan kecurangan akuntansi (fraud). Studi kasus dilaksanakan pada pengelola keuangan di PTN BLU. Pengendalian internal adalah proses pencapaian tujuan yang terdiri atas kebijakan yang melibatkan orang untuk mencapai tujuan di dalam infrastruktur maupun entitas. Sedangkan asimetri informasi sebagai bentuk ketidakseimbangan informasi antara yang diharapkan oleh pihak principal dengan agent. Penelitian ini merupakan penelitian kuantitatif dengan menggunakan teknik pengumpulan kuesioner sebagai bentuk pengumpulan datanya. Sampel penelitian ini adalah 75 pejabat pengelola keuangan pada bagian keuangan masing-masing fakultas atau unit kerja. Analisis penelitian dengan menggunakan multiple regression menunjukkan bahwa keefektifan pengendalian internal berpengaruh negatif terhadap kecenderungan kecurangan akuntansi. Sedangkan asimetri informasi berpengaruh positif terhadap kecenderungan kecurangan akuntansi.
\end{abstract}

Kata Kunci : Pengendalian, Asimetri, Kecurangan, Akuntansi

\begin{abstract}
This research aims to know the influence of asymmetric information and internal controls against the tendency of accounting fraud (fraud). This case study was conducted on the financial bureau at PTN BLU. Internal control is the objectives achievement process includes the policy of involving the people to achieve goals in the infrastructure as well as entities. While the information asymmetry as an expected information imbalances between principal and agent. This research use questionaire in order to collect the data. The samples of this research are 75 head of finance at each financial entity. Using multiple regression showed that the effectiveness of the internal control have negative effect on the tendency of accounting fraud. While other position, information asymmetry have positive effect towards the tendency of accounting fraud.
\end{abstract}

Keywords : Control, Asymentry, Fraud, Accounting

\section{Pendahuluan}

Akuntansi sebagai disiplin ilmu yang mempelajari sistem informasi serta digunakan untuk mengidentifikasi, mencatat, dan mengkomunikasikan peristiwa ekonomi dari suatu organisasi yang dibutuhkan oleh pihak-pihak berkepentingan (Weygant $d k k ., 2014$ ). Hasil dari ilmu akuntansi yakni mampu menyajikan pelaporan keuangan ke dalam laporan keuangan dan informasi yang terkait secara langsung maupun tidak langsung dengan informasi yang disediakan oleh sistem akuntansi, yaitu mengenai sumber daya perusahaan, kewajiban dan earning (Statement of Financial Accounting Concepts nomor 1). Selain itu, pelaporan keuangan seharusnya mampu memberikan informasi tentang kinerja keuangan suatu perusahaan selama satu periode secara baik dan benar.

Namun, seiring perkembangan ilmu akuntansi baik di bisnis maupun publik berkembang praktik kecurangan akuntansi diakibatkan sebagai adanya 
sistem pengendalian internal yang lemah, tidak adanya kejujuran maupun peraturan kinerja kerja yang menyebabkan kejahatan leluasa untuk melakukan aksinya (Meilaniy, 2013). Menurut Association of Certified Fraud Examiners (ACFE) (2014) kecurangan akuntansi sebagai tindakan yang dilakukan secara sengaja untuk menguntungkan diri sendiri maupun kelompok dengan merugikan pihak lain baik secara perorangan, perusahaan maupun instansi. Salah satu tindak kecurangan akuntansi, yakni korupsi (ACFE, 2014). Secara umum tingkat korupsi di Indonesia mengalami peningkatan. Hal ini dapat terlihat data dari World Bank menunjukkan peningkatan dari 26,5\% pada tahun 2011 meningkat menjadi $28,2 \%$ di tahun 2012, sedangkan pada tahun 2013 mengalami peningkatan dengan total $31,6 \%$. Data ACFE (2014) di tingkat Asia-Pacific menemukan sebanyak 129 kasus korupsi dimana 19 kasus diantaranya terjadi di Indonesia. Dibandingkan dengan negara-negara tetangga lainnya, Indonesia masih menempati posisi tertinggi dimana Malaysia hanya sebanyak 10 kasus korupsi dan Singapura dengan 8 kasus korupsi.

Menurut Indonesia Corruption Watch (ICW) (2014) dari total 19 lembaga yang ada di Indonesia, lembaga pendidikan menduduki posisi ke empat dengan jumlah 28 kasus korupsi. Sedangkan lembaga sosial kemasyarakatan (31 kasus korupsi), keuangan daerah (60 kasus korupsi), dan infrastruktur (102 kasus korupsi). Hal ini menunjukkan kasus korupsi di lembaga pendidikan masih tergolong cukup tinggi.

Tindakan yang sering dilakukan sebagai perilaku korupsi antara lain penghilangan dokumen, manipulasi bukti-bukti berupa dokumen, kesengajaan kesalahan pencatatan maupun mark up yang menyebabkan kerugian bagi perekonomian negara (Adelin, 2013). Puspitasari (2014) juga menjelaskan adanya pembuatan dokumen fiktif yang digunakan dalam proses pertanggung jawaban. Penelitian ini dilakukan pada organisasi intra kampus di salah satu perguruan tinggi hitam putih (nama universitas yang disamarkan).

ICW mengidentifikasi perilaku lain dalam bentuk kecurangan akuntansi, yakni penyuapan dan penyalahgunaan wewenang terkait perencanaan pendidikan. Salah satunya dilakukan dengan cara pengadaan laboratorium di perguruan tinggi. Selain itu, sepanjang tahun 2013 kasus korupsi banyak melibatkan pejabat tinggi PTN antara lain, di Universitas Indonesia (UI) dan Instititut Teknologi Bandung (ITB) (Nasional Kompas, 2013).

Sebagai solusi untuk menangani masalah tersebut perlu dilakukan pengendalian internal dengan tetap menggunakan prinsip-prinsip akuntansi yang berlaku secara umum. Pengendalian internal sebagai suatu tindakan maupun aktivitas yang dilakukan oleh pihak manajemen secara terus- menerus untuk memberikan keyakinan yang memadai akan tercapainya tujuan organisasi dan dapat menghindarkan terjadinya perilaku yang mengarah pada tindakan kecurangan akuntansi yang dilakukan oleh pihak internal maupun eksternal (Artini $d k k ., 2014$ ). Pengendalian internal digunakan sebagai penentuan strategi jangka panjang maupun untuk memperbaiki tingkat aktivitas operasional (Leng $d k k$. , 2014). Sebagai bentuk pengendalian internal yang baik memungkinkan pihak manajemen siap menghadapi perubahan dan persaingan global secara tepat dengan tujuan untuk meningkatkan potensi di masa yang akan datang (Tiro, 2014).

Adelin (2013) menjelaskan bahwa semakin rendah tingkat pengendalian internal, maka kemungkinan untuk melakukan kecurangan akuntansi semakin tinggi. Sebaliknya, jika tingkat pengendalian internal yang ada di dalam entitas atau organisasi dapat berjalan baik maka kecenderungan melakukan kecurangan akuntansi semakin rendah sehingga proses pelaporan keuangan yang dihasilkan dapat memberikan informasi yang relevan. Penelitian ini sejalan dengan yang dilakukan oleh Wilopo (2006) menjelaskan pengaruh faktor-faktor keefektifan pengendalian internal, kesesuaian kompensasi, ketaatan aturan akuntansi, asimetri informasi dan moralitas manajemen terhadap perilaku tidak etis dan kecenderungan kecurangan akuntansi. Sedangkan Saftarini, (2015) meneliti efektivitas pengendalian internal, asimetri informasi dan implementasi good governance terhadap kecenderungan kecurangan (fraud) akuntansi di perusahaaan BUMN cabang Pekanbaru. Demikian juga dengan penelitian yang dilakukan oleh Sari $d k k$., (2013) di SKPD Kabupaten Tabanan, Adelin (2013) dengan penelitiannya di BUMN kota Padang dan Zainal (2013) yang dilakukan di kantor cabang bank pemerintah dan swasta kota Padang.

Pengendalian internal mampu memengaruhi relevansi informasi yang merujuk pada kemampuan untuk keputusan manajer dengan melakukan perubahan mengenai hasil atau konsekuensi suatu tindakan atau kejadian. Selain itu, informasi yang disajikan harus memiliki nilai prediksi dan umpan balik, sehingga pada waktu yang bersamaan harus disampaikan dengan tepat waktu (relevan). Sedangkan reliabel merujuk ke arah penyajian informasi yang dapat diverifikasi dan jujur (Riahi dkk., 2000).

Saftarini (2015) menjelaskan selain dengan peningkatan efektivitas pengendalian internal, faktor lain yang memengaruhi kecenderungan kecurangan akuntansi adalah faktor asimetri informasi. Asimetri informasi sebagai kondisi yang menunjukkan adanya ketidakseimbangan antara informasi yang dibutuhkan oleh principal (pihak yang berkepentingan) dan agent (manajemen). Secara umum, asimetri informasi dibedakan atas dua bagian, 
yakni adverse selection dan moral hazard (Scott, 2015). Adverse selection merupakan jenis asimetri informasi dimana satu pihak atau lebih yang melangsungkan suatu proses transaksi mengetahui informasi lebih banyak atas pihak-pihak lain. Adverse selection terjadi karena manajer atau pihak yang lainnya mengetahui informasi lebih banyak di dalam perusahaan. Faktanya informasi yang dibutuhkan tidak disampaikan kepada pemegang saham. Sedangkan, moral hazard terjadi ketika salah satu pihak memanfaatkan ketidaktahuan pihak lain untuk melakukan suatu tindakan di luar kesepakatan sebelumnya.

Penelitian yang dilakukan oleh Ariani (2014) dan Saftarini dkk., (2015) menjelaskan bahwa asimetri informasi memiliki pengaruh positif terhadap kecurangan. Semakin tinggi tingkat asimetri yang terjadi, maka tingkat kecurangan akuntansi yang terjadi juga semakin tinggi. Sebaliknya, jika asimetri informasi antara pihak penyedia dan pengguna rendah maka kecenderungan akuntansinya semakin rendah.

Penelitian sebelumnya dilakukan di lembaga pemerintah dan swasta. Oleh karena itu, peneliti tertarik untuk menjelaskan lebih mendalam mengenai pengendalian internal dan asimetri informasi di subjek yang berbeda yakni pengelola keuangan di Perguruan Tinggi. Menurut data Inspektur I Kementerian Riset, Teknologi Pendidikan dan Tinggi Republik Indonesia (Menristek Dikti) (2015) secara umum permasalahan-permasalahan yang dialami di perguruan tinggi, antara lain: (a) susunan laporan keuangan belum sesuai dengan Peraturan Menteri Keuangan (PMK) 177/PMK.05/2015 tentang pedoman penyusunan dan penyampaian laporan keuangan kementerian negara/lembaga, (b) daftar isi belum sepenuhnya sesuai dengan PMK 177/PMK.05/2015, (c) belum mencamtumkan status un-audited pada cover laporan keuangan, (d) belum secara khusus dibuatkan surat keterangan (SK) tentang pengelolaan sistem akuntansi instansi.

Sedangkan permasalahan-permasalahan secara umum berdasarkan hasil Monitoring dan Evaluasi Kinerja PTN Badan Layanan Umum Tahun Anggaran 2014 menyebutkan bahwa: (a) nilai pengadaan rencana belanja tidak sesuai dengan nilai yang terealisasi pada tahun 2013 yakni selisih sebesar Rp 253.833.181.679,00, (b) belum adanya penjelasan terjadinya perbedaan antara nilai target dan pagu PNBP dalam RSB tahun 2012-2013 yang berasal dari RSB tahun 2009-2013, (c) dari segi administratif jumlah tenaga pengajar yang memiliki standar pelayanan minimal (SPM) baru mencapai 93\% dari total keseluruhan SPM, (d) belum terdapat lampiran mengenai pemberian uang muka secara jelas.
Melihat permasalahan yang terjadi, peneliti melakukan replikasi penelitian Zainal (2013), Ariani (2014) dan Saftarini (2015). Penelitian ini dilakukan pada pengelola keuangan di PTN BLU. Penelitian yang sebelumnya dilakukan di cabang bank pemerintah dan swasta di Kota Padang, PDAM dan SKPD kabupaten Bangli.

Berdasarkan latar belakang di atas, peneliti tertarik mengambil judul "Pengaruh Pengandalian Internal dan Asimetri Informasi Terhadap Kecurangan Akuntansi (Studi Kasus Pengelola Keuangan di PTN BLU Tahun 2016). Permasalahan dalam penelitian ini dirumuskan sebagai berikut: (1) Apakah pengendalian internal berpengaruh terhadap perilaku terjadinya kecenderungan kecurangan akuntansi pada pengelola keuangan di PTN BLU? (2) Apakah asimetri informasi berpengaruh terhadap perilaku terjadinya kecenderungan kecurangan akuntansi pada pengelola keuangan di PTN BLU?

Lebih lanjut, maka tujuan dari penelitian ini adalah untuk menguji: (1) pengaruh pengendalian internal terhadap perilaku kecenderungan kecurangan akuntansi pada pengelola keuangan di PTN BLU. (2) pengaruh asimetri informasi terhadap perilaku kecenderungan kecurangan akuntansi pada pengelola keuangan di PTN BLU.

\section{Tinjauan Pustaka}

\section{Teori Keagenan (Agency Theory)}

Timbulnya praktik earning management (manajemen laba) dapat dijelaskan di dalam teori keagenan. Teori ini mucul sebagai akibat adanya ketidakmampuan yang dilakukan oleh pemilik dalam hal pengelolaan perusahaan atau lembaga terkait. Sehingga, pemilik melakukan kontrak dengan agen (manajer) untuk melakukan jasa untuk kepentingan prinsipal (pemegang saham). Hanya saja agen memiliki lebih banyak informasi dan prospek perusahaan di masa yang akan datang. Scott (2014) menyatakan bahwa teori keagenan merupakan cabang ilmu yang mempelajari mengenai kontrak antara agen dan prinsipal, dimana diketahui bahwa kepentingan agen mengalami konflik dengan pihak-pihak yang berkepentingan. Terdapat beberapa masalah yang menjadi permasalahan dalam teori keagenan antara lain: (a) lemahnya kontrol yang dilakukan oleh pemegang saham terhadap manajer, (b) timbulnya perbedaan preferensi risiko dan tujuan kerja dari kedua pihak yang menyebabkan adanya biaya tambahan seperti biaya kompensasi.

\section{Kecenderungan Kecurangan Akuntansi (Fraud)}

Kecenderungan kecurangan akuntansi (Fraud) sebagai tindakan yang dilakukan secara sengaja menggunakan sumber daya internal secara tidak 
wajar dan salah dalam menyajikan fakta dengan tujuan untuk memperoleh keuntungan pribadi (Artini dkk., 2014). IAI (2001) mendefinisikan kecurangan akuntansi sebagai, (a) salah saji atau penghilangan secara sengaja jumlah atau pengungkapan dalam laporan keuangan untuk mengelabuhi pemakai laporan keuangan. (b) salah saji timbul sebagai akibat kecurangan terhadap aktiva (sebagai penyalahgunaan atau penggelapan) berkaitan dengan pencurian aktiva entitas. Kejadian ini berakibat pada proses pembuatan laporan keuangan yang disajikan tidak sesuai dengan prinsip-prinsip keuangan yang berlaku secara umum. ACFE (2012) mengkategorikan kecurangan akuntansi ke dalam tiga bagian, yakni: (a) korupsi, (b) kecurangan laporan keuangan dan (c) penyalahgunaan aset.

\section{Pengendalian Internal}

Pengendalian internal merupakan suatu proses yang dilaksanakan oleh dewan direksi, manajemen, dan personel lainnya dalam suatu entitas yang telah dirancang dan disusun yang meyakinkan bagi penggunanya dalam pencapaian tujuan antara lain: (a) keandalan dalam pembuatan pelaporan keuangan. (b) kepatuhan terhadap hukum dan peraturan yang berlaku. (c) tercapainya efektivitas dan efisiensi operasi (Boyton, 2002).

(Meliany $d k k ., 2012$ ) menjelaskan pengendalian internal sebagai kebijakan atau prosedur dengan tujuan untuk mengurangi kerugian-kerugian atas terjadinya ancaman keamanan dalam berbagai bentuk informasi. Oleh karena itu, pengendalian internal diharapkan dapat menyediakan informasi yang handal. Pengertian ini serupa dengan penjelasan dalam Peraturan Pemerintah No. 60 tahun 2008 tentang Sistem Pengendalian Internal Pemerintah (SPIP) dimana pengendalian internal merupakan suatu proses integral pada tindakan dan kegiatan yang dilakukan secara terus-menerus oleh pimpinan dan seluruh pegawai untuk memberikan keyakinan yang memadai atas tercapainya tujuan organisasi melalui kegiatan yang efektif dan efisien dengan keandalan pelaporan keuangan, pengamanan aset negara, dan ketaatan terhadap peraturan perundangundangan (Dewi, 2014).

The American Institute of Certified Public Accountant (2009) menjabarkan peran penting pengendalian internal dalam menjaga suatu entitas dari kelemahan personelnya dan mengurangi potensi kesalahan yang dibuat sehingga tidak sesuai dengan peraturan yang berlaku. Penelitian yang dilakukan Hogan et,al (2008) mendiskusikan peran auditor sebagai bagian dari system pengendalian internal dalam mengurangi potensi tindak kecurangan akuntansi. Puspasari dan Suwardi (2016) meneliti tentang pengaruh moral invdividu dan pengendalian internal terhadap kecenderungan perilaku individu untuk melakukan tindakan fraud. Ketiadaan pengendalian internal tidak berdampak bagi individu yang memiliki prinsip moral yang baik untuk melakukan tindakan fraud.

Berdasarkan pernyataan di atas, maka dapat disusun hipotesis sebagai berikut :

\section{$\mathrm{H}_{1}$ : Pengendalian Internal Berpengaruh Negatif Terhadap Kecenderungan Kecurangan Akuntansi (Fraud)}

\section{Asimetri Informasi}

Tujuan dibuatnya laporan keuangan adalah menyediakan informasi yang berguna dalam menilai kemampuan manajemen untuk menggunakan sumber daya organisasi secara efektif sebagai upaya pencapaian tujuan utama (Riahi $d k k$., 2000). Namun, terdapat salah satu kendala yang muncul sebagai akibat terjadinya ketidakseimbangan informasi antara yang diharapkan oleh pihak principal dengan agent. Kondisi seperti inilah yang dinamakan sebagai asimetri informasi. Asimetri Informasi dalam kamus bisnis diartikan sebagai keadaaan yang menunjukkan hubungan dua belah pihak yang memiliki informasi yang tidak seimbang di antara keduanya. Selain itu, asimetri informasi dapat diartikan sebagai suatu kondisi yang menunjukkan adanya ketidakseimbangan dalam akses informasi antara yang dimiliki oleh manajemen dengan pihak luar (Scott, 2014).

Penelitian yang dilakukan oleh Pradyani (2014) menjelaskan bahwa asimetri informasi sebagai kondisi dimana manajer memiliki jumlah informasi yang lebih banyak dibandingkan dengan pihak luar. Demikian halnya dengan penelitian yang dilakukan oleh (Zainal, 2013). Menurut Scott (2014) menyebutkan terdapat dua tipe asimetri informasi, yakni : adverse selection dan moral hazard.

Berdasarkan pernyataan di atas, maka dapat disusun hipotesis sebagai berikut :
$\mathrm{H}_{2}$ : Asimetri Informasi Berpengaruh Positif Terhadap Kecenderungan Kecurangan Akuntansi (Fraud)

\section{Metode Penelitian}

Penelitian ini menggunakan data kuantitatif pada subjek tertentu untuk selanjutnya diolah dan diinterpretasikan menggunakan teknik analisis kuantitatif.

Populasi penelitian adalah seluruh pengelola keuangan yang masing-masing terdapat di 16 fakultas, program pasca sarjana dan biro keuangan (BK) PTN BLU sebanyak 90 pengelola keuangan. Sesuai dengan Struktur Organisasi dan Tata Kerja di Perguruan Tinggi BLU ini tugas dan fungsi BK adalah menyelenggarakan pelayanan teknis administrasi keuangan berada di bawah dan bertanggung jawab langsung kepada Rektor. Secara 
umum Biro Keuangan mempunyai tugas memberikan layanan administrasi keuangan di lingkungan universitas. Penelitian ini dilakukan pada bulan Desember 2015-Mei 2016.

Kemudian untuk menentukan jumlah besaran sampel, masing-masing bagian keuangan hanya diberikan 5 kuesioner. Hal ini didasarkan atas perbedaan jumlah masing-masing jumlah pengelola keuangan yang terdapat di bagian keuangan tersebut. Pengecualian untuk Fakultas Ekonomi dan Bisnis (FEB) dan Fakultas Kedokteran (FK) dimana masing-masing diberikan sejumlah sembilan kuesioner.

Cara yang digunakan untuk menentukan sampel, yakni dengan menggunakan non probability sampling. Menurut Sugiyono (2013) non probability sampling merupakan teknik pengambilan sampel yang tidak memberikan kesempatan yang sama untuk populasi. Sedangkan teknik pengambilan sampel yang digunakan adalah convenience sampling. Teknik ini digunakan atas pengambilan sampel yang didasarkan pada pertimbangan tertentu. Adapun pertimbangan yang digunakan sebagai syarat dalam penentuan sampel adalah sebagai berikut: (a) tercatat sebagai pengelola keuangan di lembaga terkait. (b) subjek penelitian berkenan untuk mengisi kuesioner penelitian.

Sumber data yang digunakan dalam penelitian ini adalah sumber primer. Menurut pendapat Sugiyono (2013) sumber primer merupakan sumber data yang langsung memberikan data kepada responden yang menjadi subjek penelitian. Sedangkan teknik pengambilan data peneliti menggunakan kuesioner. Kuesioner merupakan teknik pengumpulan data yang dilakukan dengan cara memberikan seperangkat pernyataan tertulis kepada responden. Proses penyebaran kuesioner dilakukan selama satu bulan (01 Maret 2016 hingga 04 April 2016) pada masingmasing fakultas, program pasca sarjana dan BK PTN BLU.

Kuesioner disebarkan pada setiap individu yang ada pada pengelola keuangan pada masing-masing fakultas, program sarjana dan BK PTN BLU dengan jumlah maksimal lima kuesioner. Kuesioner yang diberikan telah disertai dengan surat permohonan izin untuk melakukan penelitian pada masing-masing fakultas, program sarjana dan BK PTN BLU. Jangka waktu pengambilan kuesioner berkisar antara 3- 14 hari dari awal penyebarannya.

Pada penelitian ini terdiri atas dua variabel independen, yakni pengendalian internal dan asimetri informasi. Sedangkan variabel dependen dalam penelitian ini adalah kecenderungan kecurangan akuntansi (fraud). Untuk mengukur variabel dalam penelitian ini, peneliti menggunakan acuan pada skala likert dengan rentang lima jawaban. Penjabaran operasional variable adalah sebagai berikut: Pengendalian internal merupakan kebijakan atau prosedur yang digunakan dengan tujuan untuk memberikan jaminan perusahaan sehingga dapat mencapai tujuan-tujuannya serta mampu meminimalkan terjadinya kehilangan informasi. Instrumen yang digunakan untuk mengukur dan mengidentifikasikan pengendalian internal terdiri atas 20 item pernyataan yang tersusun dari lima komponen yang diambil dari konsep COSO yaitu lingkungan pengendalian, penilaian risiko, aktifitas pengendalian, informasi dan komunikasi serta monitoring dan evaluasi. Penentuan besaran jumlah variabel ini menggunakan rentang skala ordinal yang dijabarkan ke dalam poin mulai 1 (sangat setuju) hingga 5 (sangat tidak setuju). Asimetri informasi merupakan suatu keadaan dimana manajer memiliki akses informasi atas suatu perusahaan yang tidak dimiliki oleh pihak-pihak lain, yakni pihak luar (Zainal, 2013). Instrumen yang digunakan untuk menemukan jawaban atas permasalahan ini terdiri dari 6 item pernyataan yang dirumuskan dari konsep asimetri informasi secara umum. Dua bagian asimetri informasi tersebut berdasarkan pengertian dari (Scott, 2014) adalah adverse selection dan moral hazard. Penentuan besaran jumlah variabel ini menggunakan rentang skala ordinal yang dijabarkan ke dalam poin dari 1 (sangat setuju) hingga 5 (sangat tidak setuju). Kecenderungan kecurangan akuntansi merupakan keinginan untuk melakukan segala tindakan yang bertentangan dengan aturan. Salah satu contohnya dapat dilakukan dengan melakukan penipuan, korupsi, manipulasi, atau dengan sengaja melakukan salah saji terhadap laporan keuangan. Instrumen yang digunakan dalam menemukan jawaban atas pernyataan ini terdiri dari tiga item pernyataan yang diperoleh dari Association of Certified Fraud Examiners (ACFE).

\section{Hasil Penelitian Dan Pembahasan}

Sampel pada penelitian ini berjumlah 75 orang. Hasil uji validitas menggunakan korelasi bivariate sebagai dasar untuk mengukur indikator skor dan total skor konstruk. Kemudian untuk melihat hasil uji validitas, dilakukan dengan melihat hasil output Pearson Correlation pada bagian total dari masing-masing Correlation dengan tingkat signifikansi 0,05. Adapun hasil pengukuran uji validitas dengan menggunakan program SPSS Statistics 17 for Windows.

Item pernyataan dikatakan valid jika nilai $r$ hitung lebih besar dari nilai $r$ tabel. Nilai $r$ tabel minimum untuk 72 sampel adalah 0,227. Dari keseluruhan sampel yang telah diuji menunjukkan nilai yang valid.

Pengujian reliabilitas digunakan untuk mengetahui pernyataan-pernyataan yang sudah tervalidasi dan mengetahui sejauh mana hasil pengukuran tetap stabil. Uji reliabilitas ini dikatakan reliabel jika nilai memiliki nilai Cronbach's Alpha > 0,70. Dari hasil perhitungan diperoleh nilai koefisien reliabilitas untuk variabel Keefektifan Pengendalian 
Internal $\left(\mathrm{X}_{1}\right)$ diperoleh 0,713 ; Kemudian Variabel Asimetri Informasi $\left(\mathrm{X}_{2}\right)$ sebesar 0,614; dan Fraud (Y) sebesar 0,800, nilai koefisien reliabilitas tersebut lebih besar daripada nilai kritis $(0,600)$, sehingga seluruh variabel penelitian dinyatakan reliable.

Tahap selanjutnya dilakukan pengujian atas asumsi-asumsi terdiri atas pengujian normalitas data, multikolinearitas, pengujian linearitas dan heteroskesdasitas.

Uji normalitas digunakan untuk mengetahui apakah di dalam model regresi ditemukan variabel pengganggu atau residual dengan data distribusi normal atau tidak. Sedangkan cara yang dilakukan dengan melihat normal probability plot (P-P) yang membandingkan nilai distribusi kumulatif dari distribusi normal.

Dari hasil pengujian normalitas dari grafik normal P-P plot maupun histogram dapat diketahui hasilnya sebagai berikut, pada grafik normal plot menyebar secara merata di sekitar garis diagonal. Sedangkan pada histogram menunjukkan pola distribusi yang normal dengan membentuk garis lonceng. Dengan demikian bahwa asumsi normalitas pengujian data telah terpenuhi.

Uji multikolonearitas digunakan untuk menguji apakah dalam melakukan uji model regresi ditemukan adanya korelasi antar variabel bebas (independent) atau tidak. Nilai cut off yang umum dipakai digunakan untuk menunjukkan adanya multikoloniearitas diperoleh nilai tolerance $>0,10$ atau sama dengan nilai $\mathrm{VIF}<10$. Dari hasil perhitunagn diperoleh nilai variabel bebas yang signifikan menunjukkan nilai VIF yang tidak lebih dari nilai 10, maka disimpulkan bahwa asumsi telah bebas dari multikolonieritas.

Uji linearitas digunakan untuk menguji apakah spesifikasi model dalam penelitian ini sudah linear atau tidak. Model uji yang baik adalah model dimana hubungan antara kedua variabel tersebut adalah linier. Metode yang digunakan dalam menguji linieritas adalah dengan uji estimasi kurva. Hubungan kedua variabel dikatakan linier apabila nilai signifikansi uji lebih kecil dari alpha $(0,05)$ yang digunakan. Dari hasil perhitungan diperoleh signifikansi sebesar 0,002 untuk kedua variabel independen di atas.

Uji heteroskesdastisitas digunakan untuk menguji apakah dalam model regresi terjadi ketidaksamaan variance dari residual antara satu pengamatan ke pengamatan yang lain. Untuk mengetahui ada atau tidaknya heteroskesdastisitas dapat diketahui dengan menggunakan Scatterplot.

Dari hasil pengujian heterokesdastisitas di atas bahwa titik-titik menyebar secara acak sehingga tidak membentuk pola dan mengelompok pada suatu titik. Demikian halnya dengan titik-titik yang menyebar baik di bawah maupun atas angka nol.

Dari perhitungan nilai t hitung pada variabel Keefektifan Pengendalian Internal $\left(\mathrm{X}_{1}\right)$ sebesar 2,14, nilai tersebut bernilai negatif, hal ini membuktikan bahwa hipotesis penelitian tentang $\mathrm{H}_{1}$ (Keefektifan Pengendalian Internal berpengaruh negatif terhadap Fraud) dapat diterima, sedangkan nilai -t tabel dengan derajat bebas $72(n-k-1)=$ 1,993. Bila dibandingkan maka nilai $-\mathrm{t}$ hitung $<-\mathrm{t}$ tabel $(-2,14<-1,993)$. Pengujian ini menunjukkan bahwa Keefektifan Pengendalian Internal (X1) berpengaruh signifikan terhadap Fraud (Y). Sehingga kesimpulan sampel dapat digeneralisasikan untuk populasi.

Dari perhitungan nilai t hitung pada variabel Asimetri Informasi $\left(\mathrm{X}_{2}\right)$ sebesar 3,484, nilai tersebut bernilai positif, hal ini membuktikan bahwa hipotesis penelitian tentang $\mathrm{H}_{2}$ (Asimetri Informasi berpengaruh positif terhadap Fraud) dapat diterima, sedangkan nilai t tabel dengan derajat bebas 72 (n-k$1)=1,993$. Bila dibandingkan maka nilai $t$ hitung $>t$ tabel $(3,484>1,993)$. Pengujian ini menunjukkan bahwa Asimetri Informasi $\left(\mathrm{X}_{2}\right)$ berpengaruh signifikan terhadap Fraud (Y). Sehingga kesimpulan sampel dapat digeneralisasikan untuk populasi dimana diketahui nilai $\mathrm{t}$ hitung pada variabel Keefektifan Pengendalian Internal $\left(\mathrm{X}_{1}\right)$ sebesar 2,14, nilai tersebut bernilai negatif, hal ini membuktikan bahwa hipotesis penelitian tentang $\mathrm{H}_{1}$ (Keefektifan Pengendalian Internal berpengaruh negatif terhadap kecenderungan kecurangan akuntansi) dapat diterima.

Sedangkan nilai -t tabel dengan derajat bebas $72(n-k-1)=-1,993$. Bila dibandingkan maka nilai -t hitung $<-t$ tabel $(-2,14<-1,993)$. Pengujian ini menunjukkan bahwa Keefektifan Pengendalian Internal $\left(\mathrm{X}_{1}\right)$ berpengaruh signifikan terhadap Kecenderungan Kecurangan Akuntansi (Y). Sehingga kesimpulan sampel dapat digeneralisasikan untuk populasi.

Kemudian nilai $\mathrm{t}$ hitung pada variabel Asimetri Informasi $\left(\mathrm{X}_{2}\right)$ sebesar 3,484, nilai tersebut bernilai positif, hal ini membuktikan bahwa hipotesis penelitian tentang $\mathrm{H}_{2}$ (Asimetri Informasi berpengaruh positif terhadap Fraud) dapat diterima, sedangkan nilai t tabel dengan derajat bebas 72 (n-k$1)=1,993$. Bila dibandingkan maka nilai $t$ hitung $>t$ tabel $(3,484>1,993)$. Pengujian ini menunjukkan bahwa Asimetri Informasi $\left(\mathrm{X}_{2}\right)$ berpengaruh signifikan terhadap Kecenderungan Kecurangan Akuntansi (Y). Sehingga kesimpulan sampel dapat digeneralisasikan.

Dari hasil pengujian data statistik dapat dibahas sebagai berikut: 
1. Pengaruh Keefektifan Pengendalian Internal Terhadap Kecenderungan Kecurangan Akuntansi (Fraud)

Hasil penelitian ini mendukung hipotesis yang pertama, yakni keefektifan pengendalian internal memiliki pengaruh negatif terhadap kecenderungan kecurangan akuntansi (fraud). Hal ini dibuktikan dengan nilai t hitung sebesar 2,14 . Sedangkan nilai t tabel diperoleh sebesar 1,993. Bila dibandingkan antara nilai $\mathrm{t}$ hitung dengan nilai $\mathrm{t}$ tabel $((-2,14<-1,993)$ menunjukkan bahwa bahwa keefektifan pengendalian internal $\left(\mathrm{X}_{1}\right)$ berpengaruh signifikan terhadap kecenderungan kecurangan akuntansi (Y). Hal ini semakin tinggi tingkat pengendalian internal yang diterapkan maka kecenderungan kecurangan akuntansi yang terjadi semakin rendah.

Selain mengacu dari hasil pengolahan data statistik di atas, terdapat beberapa hal yang menjadi kategori bahwa pelaksanaan dari pengendalian internal yang dilakukan pada pengelola keuangan di PTN BLU telah berjalan efektif antara lain, (1) pelaksanaan aturan-aturan yang menjadi tanggung-jawab pada masingmasing pengelola keuangan telah berjalan sesuai dengan SOP (Standart Operational Procedure). (2) Sebagai bentuk proses pelaksanaan penggunaan keuangan, bagian keuangan pada masing-masing pengelola keuangan telah melakukan proses perencanaan hingga proses pertanggung jawaban secara terperinci disertai dengan bukti-bukti dokumentasi. (3) Untuk mencegah terjadinya tindak kecurangan yang melibatkan pihak-pihak internal (pegawai, bendahara pengeluaran maupun penerimaan) masing-masing pengelola keuangan telah melaksanakan evaluasi secara kinerja secara rutin.

Penelitian ini mendukung bahwa dengan diterapkannya pengedalian internal yang efektif maka aktivitas yang dilakukan oleh manajemen secara terus-menerus dapat memberikan keyakinan yang memadai akan tercapainya tujuan organisasi (Artini, 2014). Demikian juga dengan diterapkannya gaya manajemen secara rutin dalam bentuk evaluasi kinerja secara rutin dapat meminimalkan resiko tindakan kecurangan. kategori-kategori ini yang dapat digunakan sebagai bentuk bentuk pencegahan terjadinya kecurangan terjadinya penyalahgunaan anggaran, pencurian maupun penggelapan oleh pihak-pihak yang bersangkutan. Selain itu, bagi pihak yang berkepentingan dapat menggunakan laporan keuangan secara valid dan terpercaya. Hasil penelitian ini sejalan dengan penelitian yang dilakukan oleh Delfi, dkk (2014) yang mengemukakan adanya penerapan wewenang dan tanggung-jawab, pencatatan transaksi dan dilakukannya evaluasi secara terus-menerus dapat mengurangi terjadinya tindak kecurangan akuntansi (fraud).

Disisi lain masih terdapat kategori lain yang belum dapat dijalankan secara maksimal yang menyebabkan pelaksanaan pengendalian internal belum dapat berjalan secara optimal. Adapun kategori tersebut adalah belum dilaksanakannya penggunaan teknologi yang terintegrasi seperti program SAIBA, Accurate maupun aplikasi keuangan lainnya yang bertujuan untuk menunjang kelacaran dalam pelaksanaan penggunaan anggaran.

Selain itu, hasil daripada penelitian ini didukung oleh penelitian-penelitian sebelumnya yang dilakukan oleh Kurniawan (2013). Penelitian ini menunjukkan bahwa pelaksanaan pengendalian internal cukup berjalan efektif untuk mencegah terjadinya kecurangan akuntansi (fraud). Namun, terdapat satu kategori yang menyebabkan penerapan pengendalian internal masih rendah, yakni kurangnya kompetensi pada penempatan ahli di bidangnya. Demikian pula dengan penelitian-penelitian yang dilakukan oleh Zainal (2013), Dewi (2014), Lestari (2014), Artini dkk., (2014) menunjukkan hal yang sama.

2. Pengaruh Asimetri Informasi Terhadap Kecenderungan Kecurangan Akuntansi (Fraud)

Hasil penelitian ini mendukung hipotesis yang kedua, yakni asimetri informasi memiliki pengaruh positif terhadap kecenderungan kecurangan akuntansi (fraud). Hal ini dibuktikan dengan nilai t hitung sebesar 3,484. Sedangkan nilai $\mathrm{t}$ tabel diperoleh sebesar 1,993. Bila dibandingkan antara nilai $\mathrm{t}$ hitung dengan nilai $\mathrm{t}$ tabel $(3,484<1,993)$ menunjukkan bahwa bahwa asimetri informasi $\left(\mathrm{X}_{2}\right)$ berpengaruh signifikan terhadap kecenderungan kecurangan akuntansi (Y). Hal ini semakin tinggi tingkat asimetri informasi yang terjadi maka kecenderungan kecurangan akuntansi yang terjadi semakin meningkat.

Selain mengacu dari hasil pengolahan data statistik di atas, terdapat beberapa hal yang menjadi kategori bahwa terjadinya asimetri informasi mayoritas yang terjadi pada pengelola keuangan terjadi sebelum pelaksanaan penggunaan anggaran. Hal ini sesuai dengan salah satu bentuk asimetri informasi yakni adverse selection sesuai dengan konsep yang diajukan oleh teori dalam (Scott, 2015). Adapun yang menjadi permasalahan secara parsial proses terjadinya asimetri informasi yakni proses 
pengajuan anggaran yang dapat dilakukan oleh semua pihak sub bagian keuangan baik yang memiliki kewenangan maupun tidak memiliki kewenangan. Tentunya ini dapat berakibat pada proses pertanggung jawaban laporan di kemudian hari. Oleh karena itu, perlu adanya pemberian wewenang dan tanggung-jawab secara jelas sehingga masing-masing pihak memiliki sifat saling memiliki atas penggunaan anggaran.

Hasil penelitian ini sejalan dengan yang dilakukan oleh Saftarini $d k k$., (2015) menyatakan bahwa timbulnya tindak kecurangan karena terdapat peluang bagi pihak pengelola dana untuk melakukan kecurangan. Sedangkan pihak yang dapat melakukan kecurangan hanya pihak internal instansi yang mengetahui seluk-beluk dalam hal pembuatan dan penyajian laporan keuangan yang dikarenak kurangnya transparansi atau keterbukaan dalam hal pengelolaan keuangan.

Hasil penelitiani ini konsisten dengan penelitian yang dilakukan Aranta (2013) yang menyebutkan bahwa asimetri informasi dapat diminimalisirkan dengan cara menumbuhkan rasa tanggung-jawab pada masing-masing pengelola keuangan sehingga rasa tanggung-jawab memiliki pekerjaan dapat dilaksakan secara bersama-sama. Selain itu penelitian dari Zainal (2013) menyatakan bahwa timbulnya asimetri informasi dalam sebuah perusahaan dapat memicu terjadinya kecurangan akuntansi dalam pemberian informasi yang tidak seimbang. Hal ini yang dapat merugikan perusahaan dalam menyerap informasi sebagai penentu kebijakan perusahaan.

\section{Simpulan}

Berdasarkan hasil dari temuan dari penelitian di atas, maka dapat disimpulkan sebagai berikut : (1) Pengendalian internal berpengaruh negatif terhadap kecenderungan kecurangan akuntansi (fraud). Beberapa indikator yang menjadi kategori bahwa pengendalian internal telah berjalan efektif, antara lain: (a) pelaksanaan aturan telah dilakukan sesuai dengan SOP (Standart Operational Procedure) yang berlaku. (2) siklus dari perencanaan hingga pertanggung jawaban penggunaan keuangan telah dilakukan secara baik. (3) pelaksanaan evaluasi kinerja telah dilakukan secara rutin. Dari hasil penelitian ini mendukung dari penelitian-penelitian sebelumnya yang telah dilakukan oleh Meliany dkk., (2012), Adelin (2013), Kurniawan (2013), Zainal (2013) dan Herman (2013), Dewi (2014), Lestari (2014), Artini, $d k k$ (2014), Delfi $d k k$., (2014). (b) Asimetri informasi berpengaruh positif terhadap kecenderungan kecurangan akuntansi (fraud). Hal ini didasarkan hasil penelitian yang menunjukkan bahwa asimetri informasi mayoritas terjadi sebelum pelaksanaan penggunaan anggaran. Hal ini sesuai dengan salah satu bentuk asimetri informasi yakni adverse selection. Dari hasil penelitian ini mendukung dari penelitian-penelitian sebelumnya yang telah dilakukan oleh oleh Aranta (2013), Saftarini $d k k$., (2015), Ariani $d k k$., (2014), dan Triasmara (2014).

Untuk penelitian lebih lanjut peneliti menyarankan untuk perluasan obyek penelitian tidak hanya dibatasi pada pengelola keuangan, namun juga memasukkan unsur pengawasan di perguruan tinggi seperti unit Satuan Pengawasan Internal atau unit penjaminan mutu untuk memberikan pandangan terkait keefektifan pengendalian internal di perguruan tinggi.

Adapun keterbatasan dari penelitian ini antara lain: (a) Peneliti sulit menentukan tenggang waktu pengembalian kuesioner yang telah disebar ke semua lembaga pengelola keuangan, mengingat setiap lembaga memerlukan beberapa izin yang berbeda-beda, misalnya: perizinan dari Dekan, Pembantu Dekan III, Kepala Tata Usaha dan Kepala Sub. Bagian Keuangan masing-masing lembaga pengelola keuangan. (b) Terdapat beberapa fakultas yang tidak bersedia menyerahkan secara penuh jumlah kuesioner yang telah didistribusikan.

\section{Daftar Pustaka}

Adelin, Vani. 2013. Pengaruh Pengendalian Internal, Ketaatan pada Aturan Akuntansi dan Kecenderungan Kecurangan Terhadap Perilaku Tidak Etis. Program Akuntansi Fakultas Ekonomi Universitas Negeri Padang. Padang. (Diterbitkan dalam jurnal WRA, Vol. 1, No. 2, Oktober 2013.

Albrecht, W.S., Albrecht, C.O., Albrecht, C.C., Zimbelman, M.F. 2010. Fraud Examination Fourth Edition. USA : Natorp Boulevard.

Aranta, Z. Petra. 2013. Pengaruh Moralitas Aparat Dan Asimetri Informasi Terhadap Kecenderungan Kecurangan Akuntansi (Studi Empiris Pemerintah Kota Sawahlunto). Jurusan Akuntansi Fakultas Ekonomi Universitas Negeri Padang. Padang.

Ariani, S. Ketut., Musmini, S. Lucy., \& Herawati, T. Nyoman., 2014. Analisis Pengaruh Moralitas Individu, Asimetri Informasi Dan Keefektifan Pengendalian Internal Terhadap Kecenderungan Kecurangan 
Akuntansi Di PDAM Kabupaten Bangli. Jurusan Akuntansi Universitas Pendidikan Ganesha. Singaraja. (Diterbitkan e-Journal S1 Akuntansi Universitas Pendidikan Ganesha Volume 2 No. 1 Tahun 2014).

Artini, L. H. Ni. 2014. Pengaruh Budaya Etis Organisasi Dan Efektivitas Pengendalian Internal Terhadap Kecenderungan Kecurangan Akuntansi Pada Satuan Kerja Perangkat Daerah (SKPD) Kabupaten Jembrana. Jurusan Akuntansi Universitas Pendidikan Ganesha. Bali. (Diterbitkan eJournal S1 Ak Universitas Pendidikan Ganesha Jurusan Akuntansi Program S1 Volume 2 No. 1 Tahun 2014).

Azwar, S. 2010. Sikap Manusia : Teori dan Pengukurannya. Yogyakarta : Pustaka Belajar.

Boynton, C. William., Johnson, N. Raymond., \& Kell, G. Walter. 2000 Modern Auditing Seventh Edittion. Jakarta: Erlangga.

Delfi, Tiara., Anugerah, Rita., A. A, Al., \& Desmiyanti. 2014. Pengaruh Efektivitas Pengendalian Internal Dan Kesesuaian Kompensasi Terhadap Kecenderungan Kecurangan Akuntansi (Survey Pada Perusahaan BUMN Cabang Pekanbaru). Jurusan Akuntansi Universitas Riau. Riau.

Dewi, A. K. R. S. Gusti. 2014. Pengaruh Moralitas Individu Dan Pengendalian Internal Pada Kecurangan Akuntansi (Studi Eksperimen pada Pemerintah Daerah Provinsi Bali. Program Pascasarjana Universitas Udayana. Denpasar.

Ghozali, I. 2005. Aplikasi Analisis Multivariate dengan program SPSS Edisi Ketiga. Semarang: Badan Penerbit Universitas Diponegoro.

Herman, A. Lisa. 2013. Pengaruh Keadilan Organisasi Dan Sistem Pengendalian Intern Terhadap Kecurangan (Studi Empiris pada kantor Cabang Utama Bank Pemerintah di Kota Padang. Jurursan Akuntansi Fakultas Ekonomi Universitas Negeri Padang. Padang.

Hogan, C. E., Z. Rezaee., R. A. Riley., and U. K. Velury. 2008. "Financial Statement Fraud: Insights From The Academic Literature". Auditing: A Journal of Practice and Theory, 27(2), 231-252
Ikatan Akuntansi Indonesia. 2001. Standar Profesional Akuntan Publik, Cetakan Kedua. Jakarta: Salemba Empat.

Indonesia Corrupt Watch. 2014. Tren Pemberantasan Korupsi 2014. Divisi Investigasid an Publikasi.

Jogiyanto. 2007. Metode Penelitian Bisnis. Yogyakarta: BPFE.

Kamus Besar Bahasa Indonesia online. 2016. www.google.com

Kurniawan, Gusnardi. 2013. Pengaruh Moralitas, Motivasi dan Sistem Pengendalian Intern Terhadap Kecurangan Laporan Keuangan (Studi Empsiris Pada SKPD di Kota Solok). Program Akuntansi Fakultas Ekonomi Universitas Negeri Padang. Padang.

Lestari, Tia. 2014. Pengaruh Keadilan Organisasi Dan Sistem Pengendalian Intern Pemerintah (SPIP) Terhadap Kecurangan (Fraud) Pada SKPD Kabupaten Kaur. Jurusan Akuntansi Fakultas Ekonomi dan Bisnis Universitas Bengkulu. Bengkulu.

Leng, Jianfei., \& Zhang, Lingfen. 2014. Research and Discussing on Internal Control Auditing. Scholl of Business Hohai University Nanjing. China.

Meliany, Lia., \& Hernawati, Erna. 2013. Pengaruh Keefektifan Pengendalian Internal Dan Kesesuaian Kompensasi Terhadap Kecenderungan Kecurangan Akuntansi. Jurusan Akuntansi Universitas Pembangunan Nasional. Jakarta.

Nasional.kompas.com/read/2013/08/16/0919579/ orang-orang.pintar.terjerat.korupsi.

Pradyani, P. N. A. Ni. 2014. Pengaruh Keefektifan Pengendalian Internal, Ketaatan Aturan Akuntansi Dan Asimetri Informasi Pada Akuntabilitas Organisasi Dengan Kecenderungan Kecurangan Akuntansi Sebagai Variabel Intervening. Program Pascasarjana Universitas Udayana. Denpasar.

Puspasari, Novita., Eko Suwardi. 2016. "The Effect of Individual Morality and Internal Control on The Propensity to Commit Fraud: Evidence from Local Government" Journal of Indonesian Economy and Business, Vol. 31, Number 2, 2016, 208219 
Puspitasari, Y., R. 2015. Sisi Remang Pada Pengelolaan Keuangan Anggaran Organisasi Mahasiswa "UKM-HITAM PUTIH”. Jurusan Akuntansi. Universitas Trunojoyo Madura. Madura.

Riahi, Ahmed., \& Belkaoui. 2000. Teori Akuntansi. Jakarta: Salemba empat.

Saftarini, R. Putu, Yuniarta, A. Gede., \& Sinawarti, K. Ni. 2015. Pengaruh Efektivitas Pengendalian Internal, Asimetri Informasi Dan Implementasi Good Governance Terhadap Kecenderungan Kecurangan (Fraud) Akuntansi. Program Akuntansi Universitas Pendidikan Ganesha. Singaraja. (Diterbitkan e-Journal S1 Akuntansi Universitas Pendidikan Ganesha Volume 3 No. 1 Tahun 2015).

Sari, L. P. P. Ni. 2015. Pengaruh Efektivitas Sistem Pengendalian Internal, Ketaatan Aturan Akuntansi, Persepsi Kesesuaian Kompensasi Dan Implementasi Good Governance Terhadap Kecenderungan Fraud (Studi Empiris Pada SKPD Di Kabupaten Tabanan). Program Akuntansi Universitas Pendidikan Ganesha. Singaraja. (Diterbitkan e-Journal S1 Akuntansi Universitas Pendidikan Ganesha Volume 3 No. 1 Tahun 2015).

Scott, R. William. 2015. Financial Accounting Theory Seventh Edition. United States : Pearson.

Shintadevi, F. Prekanida. 2015. Pengaruh Keefektifan Pengendalian Internal, Ketaatan Aturan Akuntansi Dan Kesesuaian Kompensasi Terhadap Kecenderungan Kecurangan Akuntansi
Dengan Perilaku Tidak Etis Sebagai Variabel Intervening Pada Universitas Negeri Yogyakarta. Skripsi Jurusan Akuntansi Fakultas Ekonomi Universitas Negeri Yogyakarta. Yogyakarta.

Sugiyono. 2012. Statistika untuk Penelitian. Bandung: CV. Alfabeta.

Tiro, A. A., Andi. 2014. Pengaruh Pengendalian Internal Dan Kompensasi Terhadap Kecenderungan Kecurangan (Fraud) Pada Pemerintah Kota Palopo. Jurusan Akuntansi Fakultas Ekonomi dan Bisnis Universitas Hasanuddin. Makassar.

Triasmara, R. M. Rr. (Tanpa Tahun) Pengaruh Efektivitas Pengendalian Intern, Kesesuaian Kompensasi Dan Asimetri Informasi Terhadap Kecenderungan Kecurangan Pada PT. Telekomunikasi Indonesia, Tbk. Jurusan Akuntansi Fakultas Ekonomi dan Bisnis Universitas Telkom.

Weygant, J.J., Kimmel, P.D., \& Kieso, D.E. 2005. Accounting Principles. 7th Edition. USA. John Wiley and Sons.

Wilopo. 2006. Analisis Faktor-Faktor Yang Berpengaruh Terhadap Kecenderungan Kecurangan Akuntansi. Simposium Nasional Akuntansi IX Padang

Zainal, Rizki. 2013. Pengaruh Efektivitas Pengendalian Intern, Asimetri Informasi Dan Kesesuaian Kompensasi Terhadap Kecenderungan Kecurangan Akuntansi (Fraud). Jurusan Akuntansi Fakultas Ekonomi Universitas Negeri Padang. Padan 